\title{
Method of Teaching Araling Panlipunan and its Effect on the Grade-10 Students' Performance in Indanan National High School Timbangan Campus- Jolo, Sulu Philippines
}

\author{
Nuryneil M. Joe \\ Mindanao State University-Sulu, Philippines
}

\begin{abstract}
This study used quasi experimental design to determine the appropriate teaching methods in history subject. The subject of the study are 64 grade 20 students at Indanan National High School -Annex .two method of teaching are studied the modular small group discussion method and the lecture discussion method in teaching the Araling Panlipunan subject .The topics are continuously presented to the students during the third quarter of the K-12 curriculum. Pretest posttest design was utilized to determine the performance of the students in the two methods of teaching .The pretest was given before the formal teaching while the posttest was given after the formal teaching.
\end{abstract}

Statistical computation and analysis was utilized to determine the mean score of the grade 10 students in the pretest and posttest revealed the following significant findings:

1. In a Focus Group Discussion the teachers favor the modular small group discussion method as the most appropriate teaching method used in history subject. The teachers participated in FGD has cited advantages of the modular small group discussion method, that the students can exercise free-well to learn the subject based on their discussion.The students can explicitly contextualize the lesson and eventually localized in their own understanding .

2. The mean difference of the scores of the grade $\mathbf{1 0}$ students do not differ significantly in the two method of teaching.

3. The mean difference of the scores in the posttest significantly differ which implies that the modular small group discussion significantly effective than the lecture discussion method.

The study concluded that the appropriate teaching method favorable to the teachers in the Focus Group Discussion is the modular small group discussion method. The teachers justified by determine advantages of the modular small group discussion method over the lecture discussion method. There is no significant difference of the mean scores of the grade 10 students in the pretest but substantial significant difference is observed in the posttest which implied that the modular small group teaching method is significantly effective than the lecture discussion method.

\section{INTRODUCTION}

$\mathrm{T}$ The implementation of the k-12 Basic Education Curriculum in Grade 10 caused deterioration of students' performance in Araling Panlipunan. The teacher's has to swerve the teaching method from the usual traditional lecture method to a method most appropriate method to suit the $21 \mathrm{st}$ century skills in line with the constructivist approach based on the pedagogical student centered where the teacher's role is more on the facilitation activities.

There are many suggestive methods of teaching that can be utilized to improve the student's performance in Araling Panlipunan and other subject areas. Some of these methods are the brain storming method, videotape method, group discussion method, lecture method with technology presentation ,panel of expert method, role playing method, report-back session, worksheets or surveys, case studies, lecture with discussion, and class discussion. These methods were not tested through scientific experimentation to confirm the effect of methods on the performance of the students in Araling Panlipunan in the rural area setting.

However as part of the advocacy and awareness enhancement, these methods were theoretically discussed in the workshop and seminars as part of the motivation of teachers to practically support the implementation of the k-12 Basic Education Curriculum. At least the teachers are given free choices to decide the selection of the methods appropriate in their classroom that suited their lesson, level of students and practically initiate activities that can be performed by their students .

As Araling Panlipunan teacher, this researcher is confronted with a problem selecting the method of teaching that is more appropriately suitable for her students in a class composed of 43 male and 44 female with a total of 87 students in a class at Indanan National High School Timbangan. It is strongly believed that a good teacher is a teacher equipped with the teaching method that would allow the students to learn more than expected. Being a newly implemented curriculum (the K-12), personally, this researcher tried so hard to make the teaching learning more 
effective. Sad to note that my experiences, skills and knowledge in using new method of teaching such as enumerated above is very limited because the theory as presented in the training, workshop and seminars are not enough to make me fully equipped with basic strategy to employ the lessons presented in the seminar .

Hence, on my own way, discovering effective methods of teaching that are appropriate and suitable to the level of my students following the theory presented in the seminar is a better step to deal with the teaching learning activities in my Araling Panlipunan class. Thus, this study is conducted to discover the most appropriate methods of teaching suitable to the level of my students. At any rate, this study was designed to compare the performances of the grade 10 students using two methods of teachings applies to a group of 87 students. The methods of teaching used in this study are Modular small group learning methods, and Lecture Discussion method .

As usual in the classroom, the teachers are setting objectives and other strategies of teaching. At the end of the class using specific teaching methods, this students as reevaluated for their learning achievements and performance. Nevertheless. This study will facilitate to discover effective and appropriate method of teaching in Araling Panlipunan .

On developing the 21 st century skills, Kleiman (2005) stressed that students across the achievement and socioeconomic spectrum need and deserve motivating, supportive instructional environments, engaging content, and the opportunity to learn in settings that support collaboration with peers, teachers, and the larger world community .Students today live digitally every day. They use the internet, text messaging, social networking, and multimedia fluidly in their lives outside of school and they expect a parallel level of technology opportunity in their academic lives. There is disconnection between the way the students live and the way they learn, and student engagement ultimately suffers, closing this gap is a challenge for our current school systems. It is necessary to search for appropriate method of teaching to teaching Araling Panlipunan lessons in line with 21 st century skills as encourage in the k-12 curriculum .

\section{MATERIALS AND METHODS}

The research methodology in this study involves research method, research site, participants, research instrument, data gathering procedure and statistical technique

\subsection{Research Design}

This study used Quasi-experimental method .it used pretest-posttest design. The study further described the performance of the Grade-10 students in Araling Panlipunan using two methods of teaching, module small group discussion method and lecture discussion method. The techniques of evaluation is using the k-12 Grade-10 evaluation procedures including the qualitative rating of the academic performance for K-12 curriculum school year 2013-
2014 (Report Guidance Office General High School,2015). 90 and above (Advanced); 85-90 (Proficient); 80-84 (Approaching Proficiency). ; 75-79 (Developing); 74 below (Beginning).

The qualitative interpretation of the academic performance as recommended by the Department of Education in relation to the K-12 curriculum. A more elaborated interpretation of the qualitative ratings is as follows:

Advanced - The student at this level exceeds the core requirements in terms of knowledge, skills and understandings, and can transfer them automatically and flexibly through authentic performance tasks.

Proficient - The student at this level has developed the fundamental knowledge and skills and core understandings and can transfer them independently through authentic performance tasks.

Approaching Proficient - The student at this level has developed the fundamental knowledge and skills and core understanding and, with little guidance from the teacher and/or with some assistance from peers, can transfer these understandings through authentic performance tasks.

Developing - The student at this level possess the minimum knowledge and skills and core understandings, but needs help throughout the performance of authentic tasks.

Beginning - The student at this level struggles with his /her understanding, prerequisite and fundamental knowledge and / or skills have not been acquired or developed adequately to aid understanding.

\subsection{Research site}

This study was conducted in Indanan municipality utilizing the G-10 students in Indanan National High SchoolTimbangan Annex in Timbangan Indanan, Sulu.

\section{Sampling Design}

The subject of the study is to determine the effectiveness of two methods of teaching using the academic performance of the students in Araling Panlipunan. The study used purposive sampling Design. Purposive sampling identified the respondents based on the purpose of the study.

\subsection{Participants}

This study used the Araling Panlipunan class in Timbangan Annex Indanan National High School. The class is composed of 87 students of which 43 are male and 44 are female. The study used the whole class adopting quasiexperimental method, utilizing pretest and posttests design. The evaluation was a teachers made test.

\subsection{Research Instruments}

This study used teacher made test based on the lessons. The pretest and posttests design was adopted to check the achievements of the students in every lesson. 
Please identify the specific lesson in the Araling Panlipunan and in what Grade level again? Refer to the DEPED curriculum guide

\subsection{Date Gathering procedure}

The instrument in the study is a validated questions identified during the orientation enhancement G-10 seminar for Teaching Araling Panlipunan. Slight revision was made to suit the objectives of the lesson.

\section{Data Analysis}

Data computation was done using statistics package for social science (SPSS) version 20. The researcher utilized the assistance of the treatment of data.

\section{6 statistical technique}

This study used descriptive and inferential statistics in the treatment of data Mean and standard Deviation was applied to determine the levels of academic performance of the students in Araling Panlipunan. The t-test dependent samples statistics was applied to determine the significant difference between academic performance in the pretest and posttests.

\section{PERFORMANCE OF GRADE 10 STUDENTS BEFORE TEACHING}

This chapter presents the performance of the grade 10 students in pretests of the two methods of teaching, the modular small group discussion method and the lecture Discussion method. The problem this study sought to answer is "Is there significant between the pretest scores of the students using two different methods of Teaching? "And the null hypothesis to be tested is "There is no significant difference between the pretest scores of the students using two different methods of Teaching."

The conduct of the pretests was used to assess the stock knowledge of the students in history subject before presentation of the lesson to be taught for the day.
The mean scores in table 4.1 shows that the grade 10 students performed better in the pretest score using lecture Discussion method $(x=7.00)$ than the mean score using modular small group discussion Method $(x=6.37)$.

Grade 10 students performed better in pretest before giving them lecture with Discussion of the teachers according to the techniques used by the teacher to present the lesson of the day. The results of the pretest is no more than to assess the stock knowledge of the students of the topic to be discussed. There is no indication of the effect of the method of Teaching used. The result of the pretest indicates that the grade 10 students have more stock knowledge before presenting the lesson using the lecture Discussion method.

Comparatively speaking the score of the students in pretest before the presentation of lessons adapting the modular small group discussion have less stack knowledge before presentation of the lesson.

Table 3.1: Mean Scores in Pretests of the Lecture Discussion And Modular Small Group Discussion Methods

\begin{tabular}{|c|c|c|c|c|}
\hline & Mean & $\mathrm{N}$ & Std. Deviation & $\begin{array}{c}\text { Std. Error } \\
\text { Mean }\end{array}$ \\
\hline $\begin{array}{c}\text { Pretest Lecture } \\
\text { Discussion }\end{array}$ & 7.00 & 68 & 4.896 & .594 \\
\hline $\begin{array}{c}\text { Pretest Small } \\
\text { Group } \\
\text { Discussion }\end{array}$ & 6.37 & 68 & 2.947 & .357 \\
\hline
\end{tabular}

The mean difference shown in table 4.2 is not significant. The t-test value at sig (2-tailed) suggests the acceptance of the null hypothesis. The data provide evidence to conclude that there is no significant difference of the pretest scores of the grade 10 students before using the two methods of teaching, the lecture Discussion method and the modular small group discussion method. However, the mean difference in the scores ot the two methods of teaching do not indicates effectiveness of teaching, it is merely an assessment of the basic knowledge of the grade 10 students in the new lessons to be presented.

Table 3.2: Mean Difference And T-Test Value Of The Scores In Pretests In The Lecture Discussion And Modular Small Group Discussion Methods

\begin{tabular}{|c|c|c|c|c|c|c|c|c|}
\hline \multicolumn{3}{|c|}{ Paired Difference } & & & & \\
\hline & Sig. 2-Pretest & Mean & Std. Error & $\begin{array}{c}\text { Interval of } \\
\text { the t } \\
\text { dftailes }\end{array}$ & difference & Deviation & Mean & Diffidence \\
\hline $\begin{array}{c}\text { Lecture - } \\
\text { small group }\end{array}$ & 0.632 & 4.725 & 0.573 & -0.511 & 1.776 & 1.104 & 67 & 0.274 \\
\hline
\end{tabular}

\section{PERFORMANCE OF THE GRADE 10 STUDENTS AFTER TEACHING}

This chapter presents the performance of the grade 10 students in history using the posttest scores in the two methods of teaching namely the lecture Discussion method and the modular small group discussion method. The research question this study sought to answer is "Is there significant difference between posttest scores of the students using modular small group discussion method and lecture Discussion method?" And the null hypothesis to be tested is "There is no significant difference between the posttest scores of the students using modular small group discussion method and lecture Discussion method."

The data shows that the grade 10 student shows better performance in the mean score of the evaluation when they taught using the modular small group discussion Teaching 
Method compared to the mean score of the grade 10 students when they are taught using the lecture Discussion method. The data indicates that the modular small group discussion method of Teaching is effective for new presentation of the lesson than the lecture Discussion method.

Inferential statistical evidence was used to analyze and carried interpretation of the scores of the students in posttest. The comparison of mean scores in table 5.1 shows that presentation of the new lesson adopting the modular small group discussion method $(x=22.71)$ is better than the mean scores when using the lecture Discussion method $(x=21.99)$.

During the presentation of the lesson using modular small group discussion method, the students are enthusiastic to read the objectives indicated in the module and the instruction specifying the tast orientation of the modular teaching. The students practically reacted and explain the presented lesson according to the experiences they have observed in the environment. The students discussed the lesson activity with the individual member of the group according to the presented lesson. After 20 minutes discussion in each group, the teacher reminded them the preparation of the reports of the summary resulted from their discussion. Several topics were presented, eventually resulted from their discussion. Several topics were presented, eventually the students performed in each group in almost the same rate of Participation. Although, there are some students who are reluctantly participate in the discussion but this is minimal in the group.

The following table of specification shows the topics that was discussed in the teaching process modular small group discussion method and lecture Discussion method. After the presentation of the lesson, the posttests was conducted.

Table 4.1: Listed Topics Discussed During Teaching

\begin{tabular}{|c|c|c|}
\hline Chapter & Tapics & Teaching Methods \\
\hline 3 & $\begin{array}{c}\text { Daloy ng ekonomiyang pambansa } \\
\text { ng kita at ugnayanng } \\
\text { pangkalahatang kita, pag impok at } \\
\text { pagkunsomo }\end{array}$ & $\begin{array}{c}\text { Modular small group } \\
\text { Discussion method }\end{array}$ \\
\hline 4 & $\begin{array}{c}\text { Implasyon patakarang piskal at } \\
\text { pananalapi }\end{array}$ & $\begin{array}{c}\text { Lecture Discussion } \\
\text { method }\end{array}$ \\
\hline
\end{tabular}

Table 4.2: Posttests Means Scores In The Lecture Discussion And Modular Small Group Discussion Methods

\begin{tabular}{|c|c|c|c|c|}
\hline Post Test & Mean & N & $\begin{array}{c}\text { Std. } \\
\text { Deviation }\end{array}$ & $\begin{array}{c}\text { Std. Error } \\
\text { Mean }\end{array}$ \\
\hline Lecture Discussion & 21.99 & 68 & 3.651 & 0.443 \\
\hline $\begin{array}{c}\text { Small Group } \\
\text { Discussion }\end{array}$ & 22.71 & 68 & 3.678 & 0.446 \\
\hline
\end{tabular}

Table 4.3 shows the mean Difference between the posttests scores adopting the modular small group discussion method and the lecture Discussion method. The mean Difference (-.721) indicates that the mean score of the students when using the modules small group discussion is substantially significant at sig (2-tailed) value (.050). The null hypothesis could be rejected since the value is considerably equal to(.050). Therefore, the result is substantially considered to have significant difference between the mean scores of the grade 10 students when adopting the modular small group discussion and the lecture Discussion method. The use of modular small group discussion method is substantially significant effective than the lecture group discussion.

Table 4.3: T-Test Value for The Posttests Scores of the Lecture Discussion and The Modular Small Group Discussion Methods

\begin{tabular}{|c|c|c|c|c|c|c|}
\hline Posttests & Std. & $\mathrm{t}$ & $\mathrm{df}$ & $\begin{array}{c}\text { Sig. (2- } \\
\text { tailed) }\end{array}$ & Mean & Deviation \\
\hline $\begin{array}{c}\text { Lecture } \\
\text { Group }\end{array}$ & Small & $\begin{array}{c}- \\
721\end{array}$ & 2.992 & -1.986 & 67 & 0.05 \\
\hline
\end{tabular}

\section{SUMMARY, CONCLUSION AND RECOMMENDATION}

This chapter presents the summary of findings, conclusion and recommendation.

\section{Summary}

This study used quasi experimental design to determine the appropriate Teaching Methods in history subject. The subject of the study are 64 grade 10 students at Indanan National High School Annex. Two methods of teaching are studied, the modular small group discussion method and the lecture Discussion method in teaching the third quarter of the K - 2 curriculum. Pretest-posttest design was utilized to determine the performance of the students in the two methods of Teaching. The pretest was gives before the formal Teaching while the posttests was given after the formal Teaching.

\section{Findings}

Statistical computation and analysis was utilized to determine the mean score of the grade 10 students in the pretest and posttests revealed the following significant findings;

1. In the Focus Group Discussion the teaching favor the modular small group discussion method as the most appropriate Teaching Method used in history subject. The teachers participated in the FGD has cited advantages of the modular small group discussion Method, that their students can exercise free-well to learn the subject based on their Discussion. The students can explicitly contextualize the lesson and eventually localized in their own understanding.

2. The mean Difference of the scores of the grade 10 students do not differ significantly in the two methods of Teaching.

3. The mean difference of the scores un the posttests significantly differ which implies that the modular small group discussion significantly effective than the lecture discussion Method.

\section{Conclusion}

The appropriate Teaching Method favorable to the teachers in the Focus Group Discussion is the modular small 
group discussion Method. The teachers justified by determined advantages of the modular small group discussion method over the lecture discussion method. There is no significant difference of the mean score of the grade 10 students in the pretest but substantial significant difference is observed in the posttest which implied that the modular small group teaching method is significantly affect than the lecture discussion method.

\section{Recommendation}

In the light of the findings and conclusion of this study, the following recommendation are forwarded:

1. The school administration in the $\mathrm{K}-12$ curriculum should strongly support the use of modular small group discussion method in teaching history specifically in the star sections.

2. The teachers should improve gradually the use of modular small group discussion method in the teaching process. The students could be improved better used the same method of teaching in the topics presented in the day.

3. The school administration should strongly motivate the teachers to make their own module based on constructivists approach and localization. The modular should concentrate on the development of the students using sustainable materials in the locality.

4. There should be a replication study to follow-up the result of this study. The following are some suggested subjects for future research: a. Effect of modular teaching in other subject areas such as English, Filipino and others.

b. Effectiveness of other methods in History teaching

c. Conduct the same study in other schools

\section{BIBLIOGRAPHY}

[1] K to 12 Curriculum Guide: ARALING PANLIPUNAN (Grade 1 to Grade 7).

[2] January 31, $2012 \mathrm{~K}$ to 12 Toolkit: Reference Guide for Teachers Educations, School Administration and Teachers. Southeast Asian Ministers of Education Organization (SEAMEO) Regiion Center for Education Innovation and Technology (INNOTECH)

[3] B. Bautista et al. ; Department of Education: When Reforms Don't Transform. Philippines Human Development Report 2008 / 2009. pp. 65-100.

[4] Batomalaque, Antonio. Basic Science Development Programs of the Philippines for International Cooperation. University of San Carlos.; Marinas, Bella and Ditapat, Maria. Philippines: Curriculum and Development. UNESCO International Bureau of Education

[5] K to 12 Basic Education Program, The March 12, 2012.

[6] E. Delos, Santos, K-12 Changes Philippine Education System. Iconnect. Vol. 1, 2012.

[7] M. Chaudry, Turkish Online Journal of Distance Education TOJDE July 2010 ISSN 1302-6488 Volume: 11 Number: 3 Article 11, Retrived Jan. 10, 2012 from https: / / todde.anadolu.edu.tr/tojde39/articles/article_11.htm

[8] Isman, Effectiveness of Instructional Design Model in Developing the Planning Teaching Skill of Teachers' College Students at King Saud University, Retrieved on Jan. 11, 2012 from http:/ / www.slideshare.net/ HishamHussein/Effectiveness-ofinstrucctional-design-model-isman-2011-in-developing-theplanning-teaching-skills-of-teachers-college-students-at-kingsaud-university

[9] P. Anandarun, Modular Method of Teaching. Retrieved on $\begin{array}{llll}\text { February 5, } & 2012 & \text { from }\end{array}$ http:/anandkab.blogspot.com/2011/04/modular-method-ofteaching.html 